\title{
Perspectives for the lionfish invasion in the South Atlantic: Are Brazilian reefs protected by the currents?
}

\author{
Osmar J. Luiz ${ }^{1, *}$, Sergio R. Floeter ${ }^{2}$, Luiz A. Rocha ${ }^{3}$, Carlos E. L. Ferreira ${ }^{4}$ \\ ${ }^{1}$ Department of Biological Sciences, Macquarie University, Sydney, New South Wales 2109, Australia \\ ${ }^{2}$ Departamento de Ecologia e Zoologia, Universidade Federal de Santa Catarina, Florianópolis, Santa Catarina 88040-900, Brazil \\ ${ }^{3}$ Section of Ichthyology, California Academy of Sciences, San Francisco, California 94118, USA \\ ${ }^{4}$ Departamento de Biologia Marinha, Universidade Federal Fluminense, Niterói, Rio de Janeiro 24001-970, Brazil
}

\begin{abstract}
The Indo-Pacific lionfish species Pterois volitans and $P$. miles are piscivorous predators that were introduced probably via aquarium release to the northwestern Atlantic approximately $15 \mathrm{yr}$ ago and rapidly spread and established through the Greater Caribbean. Possible ecological impacts of this invasion on native species are a legitimate cause for concern. Despite predictions that lionfishes will extend their range throughout most of the eastern coast of South America, they are yet to be recorded in Brazil. We present a perspective analysis of the lionfish invasion in the southwestern Atlantic by investigating patterns of fish species movement across the Amazon-Orinoco plume (AOP), a large freshwater and sediment runoff between the Caribbean and the Brazilian Provinces that represents a 'porous' barrier to dispersal for reef organisms. We analyzed records of species that have recently crossed the barrier and found that the Brazilian Province contributes a significantly higher proportion of its endemic fauna to the pool of crossers, indicating that movements of vagrant species across the AOP are more common from Brazil towards the Caribbean than vice versa. Nevertheless, despite infrequent migration southwards against the currents, our analysis indicates that such migration has occurred historically and has resulted in the establishment of new populations. Our analysis indicates that a combination of the effects of the AOP and prevailing currents along northern Brazil may slow the pace of the potential invasion, which could help eradication programs if action is taken before lionfishes become widespread and established in Brazil.
\end{abstract}

KEY WORDS: Amazon-Orinoco barrier - Exotic species - Reef fish · North Brazil Current · Vagrant · Pterois

Resale or republication not permitted without written consent of the publisher

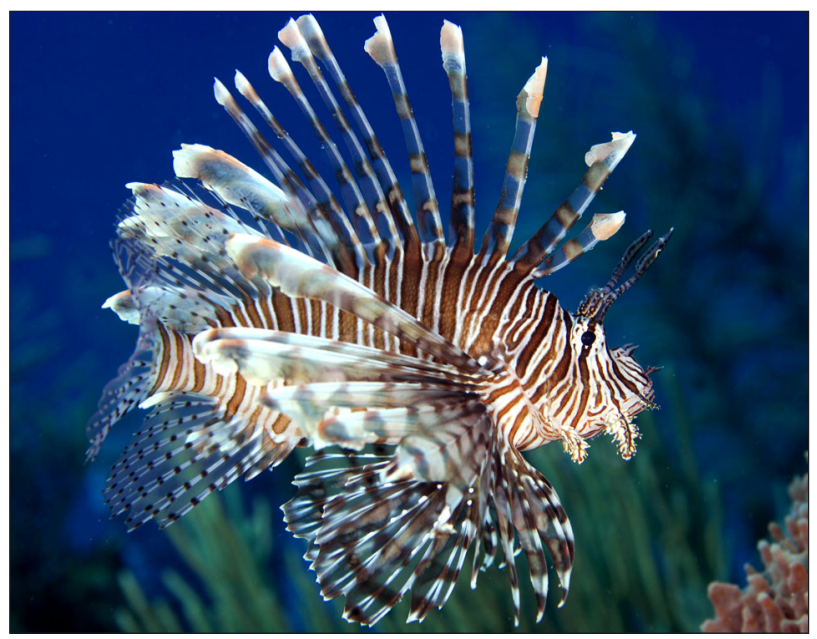

Pacific lionfish Pterois volitans have established a significant population in the Caribbean Sea and continue to expand their range.

Image: Luiz A. Rocha

\section{INTRODUCTION}

The establishment and expansion of the IndoPacific lionfish species Pterois volitans and P. miles (hereafter referred to as lionfish) in the western North Atlantic and the Caribbean Sea is among the most studied and better-documented marine fish invasions to date. Over the past decade, we have witnessed an increase in lionfish populations along the US east coast and their rapid spread over the entire Greater Caribbean (Schofield 2010, Betancur-R. et al. 2011). The lionfish invasion is predicted to be the most ecologically impacting marine invasion ever recorded (Albins \& Hixon 2011). Invasive lionfish prey on a wide range of native fish species (Côté et 
al. 2013), and their dietary breadth is much higher at invaded localities than in their native range, possibly because of prey naïveté towards the unknown invasive predator (Cure et al. 2012). Due to a suite of predatory characteristics and behaviors that has no parallel in the Atlantic (Albins \& Lyons 2012, Albins 2013), lionfish are apparently more efficient in prey capture relative to potential competitors in the invaded range (Albins 2013). Field experiments have demonstrated that lionfish reduce recruitment of native species in coral reef patches, including important functional groups such as the parrotfishes (Albins \& Hixon 2008, Green et al. 2012). The reduction in the abundance of native fishes caused by lionfish in controlled experiments was 2.5 times greater than that caused by a similarly sized native predator (Albins 2013), suggesting that lionfish can outcompete native predators.

Moreover, because large groupers, the most likely potential predators of lionfish in the Caribbean (Maljkovic et al. 2008, Mumby et al. 2011), were decimated by overfishing throughout most of the invasive range (Sadovy de Mitcheson et al. 2013), lionfish populations have grown unchecked, reaching biomass estimates 6 to 13 times greater than in their native range (Darling et al. 2011, Kulbicki et al. 2012). Measures to deter the spread of lionfish are considered by some to be ineffective and/or to have the potential to cause more harm than good (Barbour et al. 2011, Nuñez et al. 2012). The future of Caribbean reef fishes faces a bleak perspective (Albins \& Hixon 2011). Therefore, we ask how wide the geographic expansion of lionfish in the Atlantic Ocean can be in order to predict whether there are other areas under imminent threat.

\section{THE AMAZON-ORINOCO BARRIER}

The coast and oceanic islands of Brazil comprise all of the tropical western south Atlantic, characterizing the Brazilian Province (Floeter et al. 2008), which is separated from the Greater Caribbean region by the Amazon-Orinoco Plume (AOP; Fig. 1), a formidable outflow of freshwater and sediment discharged from the Amazon and Orinoco Rivers on the northeastern coast of South America. The AOP influences a large stretch $(\sim 2300 \mathrm{~km})$ of coastline and is a significant barrier for the dispersal of coral reef organisms (Rocha 2003), accounting for a significant level of endemism among reef fishes in both the Greater Caribbean and the Brazilian Province (Floeter et al. 2008). Nevertheless, the AOP is a 'porous' barrier, allowing for species that share a set of characteristics or traits to have continuous ranges from the Caribbean to Brazil (Luiz et al. 2012). Generalized habitat requirements, a broad latitudinal range, and large body size are among the traits that correlate with reef fish species living on both sides of the AOP (Luiz et al. 2012). More specifically, large generalist species, which can use a variety of habitats other than reefs and can tolerate a broad range of seawater temperature, depth, and salinity, are more likely to cross the AOP.

Lionfish are expected to eventually cross the AOP and expand their range all the way to temperate South America because they possess all of the traits related to such an expansion. First, they are versatile in their habitat requirements: in the Caribbean, as well in their native range, lionfish have been recorded in mangroves, soft bottoms, and seagrass habitats in addition to coral reefs (Claydon et al. 2012, Kulbicki et al. 2012). It is noteworthy that, within their native range, the densities of lionfish trawled over soft bottoms are the same or higher than those detected using underwater visual census on coral reefs (Kulbicki et al. 2012). Lionfish are also

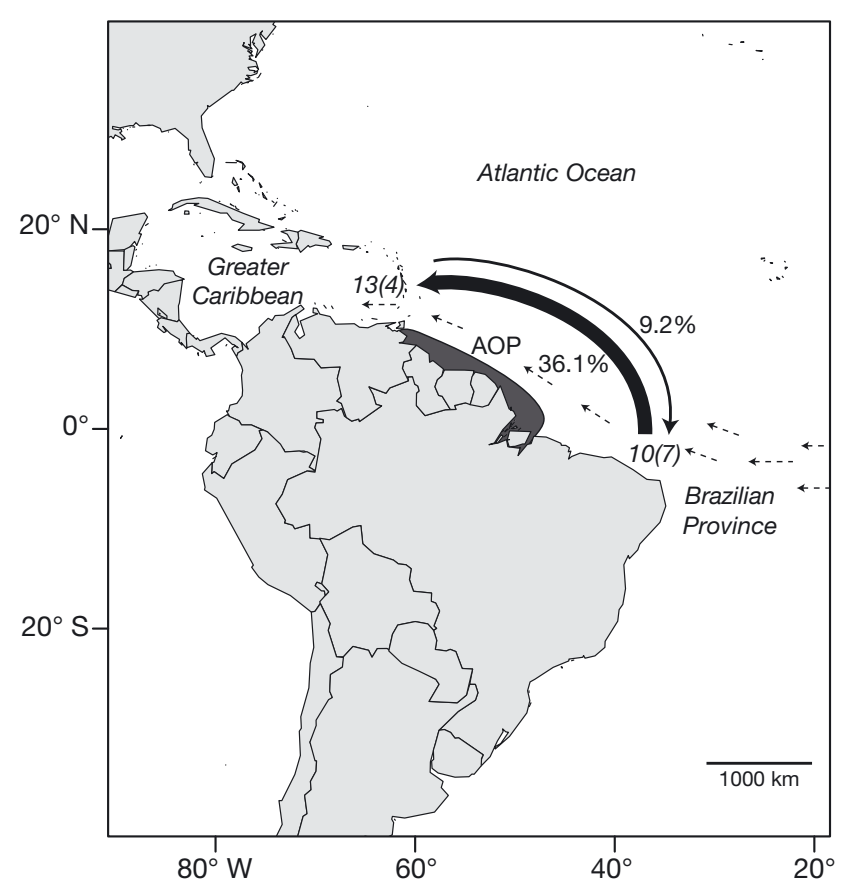

Fig. 1. Reef fish species movement across the AmazonOrinoco Plume (AOP). Thickness of solid arrows represents the intensity of migration across the AOP in each direction, with the percentage of crossing endemics from each region. Italics: total numbers of crosser species, with the number of established crosser species in parentheses. Dashed arrows show general direction of the North Brazil Current. Dark grey: the area under influence of the AOP 
known to use mangroves, the most common shore habitat within the AOP. Although no information is available about their densities in mangroves within their native range (Kulbicki et al. 2012), in their invasive range, lionfish densities in mangroves are reported to be 2.6 times higher than in adjacent reef habitats (Barbour et al. 2010). Second, lionfish thrive on deep reefs (Meister et al. 2005, Kulbicki et al. 2012). In their native range, the deepest record was at $75 \mathrm{~m}$ (Kulbicki et al. 2012). In their invasive range, however, lionfish have been recorded down to between 100 and $300 \mathrm{~m}$ (Meister et al. 2005; www. youtube.com/watch? $\mathrm{v}=\mathrm{kOHeFoIRW-g),} \mathrm{which} \mathrm{poten-}$ tially allows them to survive on the deep sponge beds below the superficial freshwater layer of the AOP (Rocha 2003). Clearly, lionfish are well equipped to move across the AOP through shallow and deep habitats.

Lionfish also have a broad latitudinal range due to their wide temperature tolerance (Kimball et al. 2004). In their native range in the Pacific, the lionfish range extends from the coast of South Korea at $35^{\circ} \mathrm{N}$ to New Zealand at $34^{\circ} \mathrm{S}$. Both regions have a mean sea surface temperature of $19^{\circ} \mathrm{C}$ and a minimal average winter temperature of $14^{\circ} \mathrm{C}$ (Kulbicki et al. 2012). In the Atlantic, lionfish have been recorded as far north as Massachusetts $\left(42^{\circ} \mathrm{N}\right)$ on the east coast of the USA, although the limit for established, yearround populations is considered to be at $35^{\circ} \mathrm{N}$, off the coast of North Carolina, USA (Schofield 2010). The lower thermal limit for lionfish survival is approximately $12^{\circ} \mathrm{C}$ (Kimball et al. 2004). Models based on habitat availability and temperature tolerance have predicted that lionfish will extend their range as far south as the coast of Uruguay $\left(35^{\circ} \mathrm{S}\right)$, in the southern part of eastern South America (Morris \& Whitfield 2009). All of the characteristics above indicate that lionfish have a wide environmental tolerance, which, combined with the rapidity of their expansion over the western North Atlantic and the Caribbean Sea, lead us to think that they would readily cross the AOP barrier towards Brazil soon after reaching the north continental shore of South America, in the southern Caribbean.

However, at the time of writing this paper, it has been roughly $3.5 \mathrm{yr}$ since lionfish were detected in the southern Caribbean, and they have not yet been recorded in Brazil. Lionfish were detected for the first time in the southern Caribbean region on the islands of Bonaire and Curaçao, Netherlands Antilles, in October 2009 (Schofield 2010). One month later, lionfish were seen on the Venezuelan coast and oceanic islands of the Los Roques Archipelago (Lasso-Alcalá
\& Posada 2010). Since then, we have been waiting for the first record of lionfish in Brazilian waters. It is noteworthy that lionfish took about the same amount of time (from 2007 to 2009) to spread over the entire Caribbean Sea since they were first detected south of the Bahamas (Schofield 2010).

The lack of lionfish sightings in Brazil is not due to lack of sampling effort, as reef fish assemblages in the tropical coast of Brazil have been well studied. Research groups from the major universities along the Brazilian coast have been sampling reefs intensively. The reef fish fauna of the 4 Brazilian oceanic islands have been constantly monitored for at least the past $10 \mathrm{yr}$. An ongoing government-funded monitoring program of reef habitats has been taking place at 13 locations along the Brazilian coast and oceanic islands (from latitudes 1 to $28^{\circ} \mathrm{S}$ ) for the past $2 \mathrm{yr}$, and no lionfish have been recorded to date (www.sisbiota.ufsc.br). In addition, there are several popular recreational dive destinations in the region. Lionfish are very conspicuous species, well known for their ornamental value and by the popular media generated after the Caribbean invasion. It is thus very unlikely that a lionfish invasion in Brazil would go unnoticed for long.

\section{ANALYSIS AND CONCLUSIONS}

An understanding of the factors hindering the lionfish propagation to the south Atlantic is important to anticipate the final spread of the invasion. In addition, this information can add to the debate on the mechanisms underlying the effectiveness of barriers to dispersal in the Atlantic. One point that was not explored in detail in the recent analysis by Luiz et al. (2012) is the directionality of barrier crossing. Evidence from phylogeographic analyses of some widespread species living on both sides of the AOP indicates more migration from the Brazilian Province towards the Greater Caribbean than in the opposite direction (Rocha et al. 2008). This pattern is probably caused by the direction of the surface flow of the North Brazil Current (Rocha et al. 2008), which varies seasonally in strength, but flows steadily northwards (Philander 2001). However, it is yet unknown whether this directionality in genetic connectivity translates into a directional bias of species migration over the AOP barrier.

We tested whether such bias exists, using a dataset of native species in either the Caribbean or Brazil that were recorded only as vagrant individuals on the opposite side of the AOP barrier. This dataset is a compilation of literature records of species occurrences plus our personal observations (Table 1). Vagrants are 
Table 1. Species, province of origin, population status, and distribution outside the province of origin of the reef fish taxa used in the analysis

\begin{tabular}{|c|c|c|}
\hline Family/species & Status/distribution & Source \\
\hline \multicolumn{3}{|l|}{ Province of origin: Brazil } \\
\hline \multicolumn{3}{|l|}{ Acanthuridae } \\
\hline Acanthurus bahianus & Vagrant/Cuba & $\begin{array}{l}\text { Bernal \& Rocha (2011), Castellanos-Gell } \\
\text { et al. (2012) }\end{array}$ \\
\hline \multicolumn{3}{|l|}{ Chaenopsidae } \\
\hline Emblemaria australis & Vagrant/Venezuela & Robertson \& Van Tassel (2012) \\
\hline \multicolumn{3}{|l|}{ Congridae } \\
\hline $\begin{array}{l}\text { Heteroconger camelopardalis } \\
\text { Haemulidae }\end{array}$ & Established/Tobago & D. R. Robertson (pers. comm.) \\
\hline Anisotremus moricandi & $\begin{array}{l}\text { Established/Venezuela, Curaçao, } \\
\text { Colombia, Panama }\end{array}$ & Rocha (2002), Robertson \& Van Tassel (2012) \\
\hline \multicolumn{3}{|l|}{ Labridae } \\
\hline Sparisoma amplum & Vagrant/St. Vincent & Wilk (2003) \\
\hline S. axillare & Vagrant/Venezuela & Robertson et al. (2006) \\
\hline S. frondosum & Established/Venezuela & Rocha (2002), authors' pers. obs. \\
\hline \multicolumn{3}{|l|}{ Opistognathidae } \\
\hline Opistognathus sp. & Vagrant/Tobago, Venezuela, St. Vincent & Rocha (2002), Robertson \& Van Tassel (2012) \\
\hline \multicolumn{3}{|l|}{ Pomacanthidae } \\
\hline Centropyge aurantonotus & $\begin{array}{l}\text { Established/Barbados, Bonaire, Curaçao, } \\
\text { St. Lucia }\end{array}$ & $\begin{array}{l}\text { Blasiola (1976), Rocha (2002), Robertson \& } \\
\text { Van Tassel (2012) }\end{array}$ \\
\hline \multicolumn{3}{|l|}{ Pomacentridae } \\
\hline Chromis jubauna & Vagrant/Tobago & Rocha (2003), Robertson \& Van Tassel (2012) \\
\hline Stegastes pictus & Vagrant/Antigua, Tobago & Rocha (2002), Robertson \& Van Tassel (2012) \\
\hline \multicolumn{3}{|l|}{ Ptereleotridae } \\
\hline Ptereleotris randalli & $\begin{array}{l}\text { Vagrant/Barbados, Bonaire, St. Vincent, } \\
\text { Tobago }\end{array}$ & Rocha (2002), Robertson \& Van Tassel (2012) \\
\hline \multicolumn{3}{|l|}{ Tetraodontidae } \\
\hline Canthigaster figueiredoi & Vagrant/Tobago, Venezuela & Rocha (2002) \\
\hline \multicolumn{3}{|l|}{ Province of origin: Caribbean } \\
\hline \multicolumn{3}{|l|}{ Chaetodontidae } \\
\hline Chaetodon ocellatus & $\begin{array}{l}\text { Established/NE coast of Brazil and } \\
\text { Fernando de Noronha Is. }\end{array}$ & Authors' pers. obs. \\
\hline \multicolumn{3}{|l|}{ Haemulidae } \\
\hline Haemulon chrysargyreum & Established/Fernando de Noronha Is. & Authors' pers. obs. \\
\hline Haemulon melanurum & Established/NE coast of Brazil & Rocha (2003) \\
\hline \multicolumn{3}{|l|}{ Labridae } \\
\hline Halichoeres bivittatus & Established/NE coast of Brazil & Rocha (2003), Rocha et al. (2005) \\
\hline Halichoeres radiatus & $\begin{array}{l}\text { Established/Fernando de Noronha Is. } \\
\text { and S. Paul's Rocks }\end{array}$ & Rocha et al. (2005) \\
\hline Lachnolaimus maximus & Vagrant/NE coast of Brazil & C. L. Sampaio (pers. comm.) \\
\hline Scarus guacamaia & Vagrant/NE coast of Brazil & Ferreira et al. (2005) \\
\hline \multicolumn{3}{|l|}{ Lutjanidae } \\
\hline Lutjanus bucanella & Established/NE coast of Brazil & Feitoza et al. (2005) \\
\hline Lutjanus mahogoni & Vagrant/NE coast of Brazil & Rocha (2003) \\
\hline \multicolumn{3}{|l|}{ Pomacentridae } \\
\hline Chromis scotti & Established/NE coast of Brazil & Rocha (2003) \\
\hline
\end{tabular}

likely a result of a sporadic spillover of larvae and/or juveniles from their native province and occur as temporary strays with no established populations in the neighboring province, and are therefore assumed to have recently crossed the barrier. They provide a 'natural experiment' opportunity to obtain insights into the directionality of the movement of species across the barrier. For example, if the proportion of endemics from the Caribbean found as vagrants in Brazil is similar to the proportion of endemics from Brazil found as vagrants in the Caribbean, we might consider that the chance of species movement is similar in both direc- tions. Alternatively, one of the provinces contributing a higher proportion of vagrant species than the other would provide evidence of directional movement across the barrier. Since the overall diversity is higher in the Caribbean, we expect this region to export more species.

We found that 9 endemic species from Brazil have been recorded as vagrants in the Caribbean, whereas only 3 Caribbean endemics have been found as vagrants in Brazil (Table 2). We counted the number of endemics (only conspicuous, non-cryptic families, to avoid problems associated with species detection 
Table 2. Summary of binomial test of proportions of species from each biogeographic province that have recently crossed the Amazon-Orinoco Plume (AOP). Bold: significance $(p<0.05)$. As a conservative measure to avoid problems associated with species detection and identification, we included only endemics of the non-cryptic and conspicuous families Acanthuridae, Aulostomidae, Chaetodontidae, Epinephelidae, Grammatidae, Haemulidae, Labridae (including Scarinae), Lutjanidae, Monacanthidae, Mullidae, Pomacanthidae, Pomacentridae, Serranidae, and Tetraodontidae. To recalculate the percentage of all putative crossers (parentheses), recent established species (Table 1) were included in the total pool of endemic species

\begin{tabular}{|c|c|c|c|c|c|}
\hline & \multicolumn{2}{|c|}{ _ Province $\_$} & \multirow{2}{*}{$\chi^{2}$} & \multirow[t]{2}{*}{ df } & \multirow[t]{2}{*}{$p$} \\
\hline & Caribbean & Brazil & & & \\
\hline Endemic spp. & 101 & 31 & - & - & - \\
\hline $\begin{array}{l}\text { Vagrants of } \\
\text { endemics across } \\
\text { the AOP }\end{array}$ & $3(2.9)$ & $9(29.0)$ & 19.736 & 1 & 0.000 \\
\hline $\begin{array}{l}\text { Spp. recently } \\
\text { established across } \\
\text { the AOP }\end{array}$ & SS & 4 & - & - & - \\
\hline $\begin{array}{l}\% \text { of all putative } \\
\text { crossers }\end{array}$ & 9.2 & 36.1 & 12.573 & 1 & 0.000 \\
\hline
\end{tabular}

and identification; see list in Table 2) from each region that may occur as vagrants across the AOP. Vagrant species escaping their native province represent 29.0 and $2.9 \%$ of the endemic fishes from the Brazilian Province and Greater Caribbean, respectively. Despite its lower species richness, the Brazilian Province contributes a significantly higher proportion of its endemic fauna to the pool of vagrant strays found across the AOP barrier (binomial test of proportions [Crawley 2005]; $\chi^{2}=19.736, \mathrm{df}=1, \mathrm{p}=$ 0.000 ), suggesting that species are crossing the AOP from south to north much more often than in the opposite direction.

The definition of vagrant species we used here may underestimate the detection of migration across the AOP because it excludes recent migrants that may have established small self-sustaining populations in the new province after crossing the barrier. Therefore, we expanded our analysis to include species that are widespread in either the Brazilian Province or the Greater Caribbean but resident in a single locality and/or have a very limited distribution on the opposite side of the AOP barrier. This adds 4 species that crossed recently into the Caribbean and 7 species that recently arrived in Brazil (Table 2). The inclusion of those species in the pool of endemics barely changes the proportion of crossers from each province: 36.1 and $9.2 \%$ of the Brazilian and Caribbean endemics, respectively $\left(\chi^{2}=12.573, \mathrm{df}=1\right.$, $\mathrm{p}=0.000$; Fig. 1)
These results are consistent with the general direction of surface flow of the North Brazil current and with migration estimates from genetic datasets (Rocha et al. 2008). Ecological traits are receiving increasing attention as a way to understand dispersal of reef fish species (Luiz et al. 2012). However, the present study shows that, at least in some cases, oceanography must be accounted for in traits-based analyses aimed to predict the direction of dispersal of reef fishes.

A spatial analysis of the invasion has detected that transport by currents is the most important factor controlling the path of lionfish spread in the western North Atlantic and Caribbean Sea (Johnston \& Purkis 2011). This observation is in line with the notion that the strong inflow of the North Brazil Current into the Caribbean has been delaying the lionfish spread to the southwestern Atlantic. However, the porous nature of the AOP barrier suggests that the risk of invasion, although likely to be small, still exists. Transport southward from the Caribbean may be infrequent because it goes against the currents, but as our analysis indicates, it has occurred in the past and can result in the establishment of new populations. With lionfish becoming more abundant and widespread in the Greater Caribbean, we believe that, given enough time, they will eventually reach the western South Atlantic. It is likely that the first sightings of a lionfish in Brazilian waters will occur either in the Fernando de Noronha Archipelago or the Rocas Atoll because of an apparent strong connectivity linking the Caribbean with those islands that is not mirrored in the rest of the Brazilian Province (Rocha et al. 2005). These islands are also the place where lionfish can do the most damage; the islands are small and host several endemics that will likely have their already small populations impacted by the arrival of a new predator (Hawkins et al. 2000).

The richness of non-native species established in a given area is often related to the influx rate of migrating species to that area (i.e. colonization pressure; Lockwood et al. 2009). Our analysis shows that despite a higher colonization pressure towards the Caribbean, the successful establishment of migrant species is apparently more common in Brazil. Among the 10 species that are originally from the Caribbean and recently crossed to Brazil, 7 are established, whereas only 4 out of the 13 Brazilian endemics that have recently crossed towards the Caribbean are established (Fig. 1). The reason for this may be a greater invasion resistance due to the greater species diversity in the Caribbean. One of the tenets of the 'biotic resistance' concept is that successful invaders are generally natives from places with higher species 
richness than the area they have invaded (Kimbro et al. 2013). It is suggested that they have evolved in a more complex and more competitive habitat, thus being better competitors than species that originated in poorer and low-competition environments (Briggs 2010). Our analysis is consistent with this observation among western Atlantic reef fishes. This process may also explain the success of lionfish in the Caribbean, since they are native to the world's most diverse marine region.

Based on the predictions above, the arrival of lionfish in Brazilian reefs may cause even more problems than what has been suggested for the Greater Caribbean. The lower species richness and simpler ecosystems in the Brazilian Province suggest that lionfish will establish and spread even faster and have fewer competitors, with potential dire consequences to the native fauna. Nevertheless, there are some alternative scenarios to consider if one analyzes the present status of reef fish communities in Brazil. Because predators have been intensely overfished along the Brazilian coast (Floeter et al. 2006), it is reasonable to assume that there is ample niche space to be re-occupied. For example, in Rocas Atoll, among the most pristine reef environments in Brazil, the biomass of top predators is roughly 4 -fold that of the coastal reefs (authors' unpubl. data). Trophic cascades emerging after decades of overfishing on top predators may suggest that an invasive meso-predator like the lionfish would not be as disastrous as claimed due to a higher biotic resistance offered by abundant native meso-predators. A recent study indicates that lionfish may outcompete native meso-predators (Albins 2013); however, that study consisted of experimental manipulation of fish densities on patch reefs, which may not reflect conditions at the contiguous coastlines that characterize Brazilian reefs.

The low efficacy of lionfish removal and control programs in some Caribbean nations stems from constant recolonization from multiple source populations (Barbour et al. 2011). As we show here, the North Brazil Current flow is apparently a significant hurdle for lionfish migration, which may result in rare and sporadic long-distance recruitment pulses in Brazil outsourced from Caribbean populations. From a management perspective, this reduced propagule pressure would make removal and control programs an achievable goal in Brazil, although only if action is taken before lionfish become widespread and established.

The ability to make decisions and act quickly on evidence of environmental threat greatly influences the outcome of conservation measures (Martin et al.
2012). Particularly in the case of exotic species invasions, prevention, early detection, and rapid response to eradication are more effective, less costly, and less risky than later interventions when the invaders are established and interacting with the native community (Simberloff et al. 2013). In spite of the different and uncertain scenarios that could emerge from the lionfish invasion in the Brazilian Province, as a precautionary action we recommend that selected sites on Brazil's northeastern coast and oceanic islands should be monitored for lionfish occurrences; moreover, we recommend establishing an eradication program to commence immediately at the first occurrence.

Acknowledgements. Financial support was provided by an International Macquarie University Research Excellence Scholarship to O.J.L., CNPq (productivity grants to S.R.F. and C.E.L.F.), SISBIOTA-Mar (CNPq 563276/2010-0 and FAPESC 6308/2011-8) and the California Academy of Sciences (to L.A.R.). We thank K. Cure, D. Barneche, D. R. Robertson, and 3 anonymous reviewers for comments on the manuscript. We also thank C. L. S. Sampaio for sharing unpublished pictures of an individual hogfish Lachnolaimus maximus caught in NE Brazil.

\section{LITERATURE CITED}

Albins MA (2013) Effects of invasive Pacific red lionfish Pterois volitans versus a native predator on Bahamian coral-reef fish communities. Biol Invasions 15:29-43

Albins MA, Hixon MA (2008) Invasive Indo-Pacific lionfish Pterois volitans reduce recruitment of Atlantic coral-reef fishes. Mar Ecol Prog Ser 367:233-238

Albins MA, Hixon MA (2011) Worst case scenario: potential long-term effects of invasive predatory lionfish (Pterois volitans) on Atlantic and Caribbean coral-reef communities. Environ Biol Fishes, doi: 10.1007/s10641-011-9795-1

Albins MA, Lyons PJ (2012) Invasive red lionfish Pterois volitans blow directed jets of water at prey fish. Mar Ecol Prog Ser 448:1-5

> Barbour AB, Montgomery ML, Adamson AA, Díaz-Ferguson E, Silliman BR (2010) Mangrove use by the invasive lionfish Pterois volitans. Mar Ecol Prog Ser 401:291-294

Barbour AB, Allen MS, Frazer TK, Sherman KD (2011) Evaluating the potential efficacy of invasive lionfish (Pterois volitans) removals. PLoS ONE 6:e19666

Bernal MA, Rocha LA (2011) Acanthurus tractus Poey, 1860, a valid western Atlantic species of surgeonfish (Teleostei, Acanthuridae), distinct from Acanthurus bahianus Castelnau, 1855. Zootaxa 2905:63-68

$>$ Betancur-R. R, Hines A, Acero A, Orti G, Wilbur AE, Freshwater DW (2011) Reconstructing the lionfish invasion: insights into Greater Caribbean biogeography. J Biogeogr 38:1281-1293

Blasiola GC Jr (1976) Centropyge aurantonotus Burgess, 1974 (Pisces: Chaetodontidae): range, extension, and redescription. Bull Mar Sci 26:564-568

> Briggs JC (2010) Marine biology: the role of accommodation in shaping marine biodiversity. Mar Biol 157:2117-2126

Castellanos-Gell J, Robainas-Barcia A, Casane D, Cheva- 
lier-Monteagudo P, Pina-Amargos F, Garcia-Machado E (2012) The surgeonfish, Acanthurus bahianus, has crossed the Amazon-Orinoco outflow barrier. Mar Biol 159:1561-1565

> Claydon JAB, Calosso MC, Traiger SB (2012) Progression of invasive lionfish in seagrass, mangrove and reef habitats. Mar Ecol Prog Ser 448:119-129

> Côté IM, Green SJ, Morris JA Jr, Akins JL, Steinke D (2013) Diet richness of invasive Indo-Pacific lionfish revealed by DNA barcoding. Mar Ecol Prog Ser 472:249-256

Crawley MJ (2005) Statistics: an introduction using R. J Wiley, Chichester

> Cure K, Benkwitt CE, Kindinger TL, Pickering EA, Pusack TJ, Mcllwain JL, Hixon MA (2012) Comparative behavior of red lionfish Pterois volitans on native Pacific versus invaded Atlantic coral reefs. Mar Ecol Prog Ser 467:181-192

> Darling ES, Green SJ, O'Leary JK, Côté IM (2011) IndoPacific lionfish are larger and more abundant on invaded reefs: a comparison of Kenyan and Bahamian lionfish populations. Biol Invasions 13:2045-2051

Feitoza BM, Rosa RS, Rocha LA (2005) Ecology and zoogeography of deep-reef fishes in northeastern Brazil. Bull Mar Sci 76:725-742

Ferreira CEL, Gasparini JL, Carvalho A, Floeter SR (2005) A recently extinct parrotfish species from Brazil. Coral Reefs 24:128

> Floeter SR, Halpern BS, Ferreira CEL (2006) Effects of fishing and protection on Brazilian reef fishes. Biol Conserv 128:391-402

Floeter SR, Rocha LA, Robertson DR, Joyeux JC and others (2008) Atlantic reef fish biogeography and evolution. J Biogeogr 35:22-47

> Green SJ, Akins JL, Maljkovic A, Côté IM (2012) Invasive lionfish drive Atlantic coral reef fish declines. PLoS ONE 7:e32596

> Hawkins JP, Roberts CM, Clark V (2000) The threatened status of restricted-range coral reef fish species. Anim Conserv 3:81-88

Johnston MW, Purkis SJ (2011) Spatial analysis of the invasion of lionfish in the western Atlantic and Caribbean. Mar Pollut Bull 62:1218-1226

Kimball ME, Miller JM, Whitfield PE, Hare JA (2004) Thermal tolerance and potential distribution of invasive lionfish (Pterois volitans/miles complex) on the east coast of the United States. Mar Ecol Prog Ser 283:266-278

Kimbro DL, Cheng BS, Grosholz ED (2013) Biotic resistance in marine environments. Ecol Lett 16:821-833

> Kulbicki M, Beets J, Chabanet P, Cure K and others (2012) Distributions of Indo-Pacific lionfishes Pterois spp. in their native ranges: implications for the Atlantic invasion. Mar Ecol Prog Ser 446:189-205

> Lasso-Alcalá OM, Posada JM (2010) Presence of the invasive red lionfish, Pterois volitans (Linnaeus, 1758), on the coast of Venezuela, southeastern Caribbean Sea. Aquat Invasions 5:S53-S59

> Lockwood JL, Cassey P, Blackburn TM (2009) The more you introduce the more you get: the role of colonization pressure and propagule pressure in invasion ecology. Divers Distrib 15:904-910

Luiz OJ, Madin JS, Robertson DR, Rocha LA, Wirtz P, Floeter SR (2012) Ecological traits influencing range expansion across large oceanic dispersal barriers: insights from

Editorial responsibility: Tim McClanahan,

Mombasa, Kenya tropical Atlantic reef fishes. Proc R Soc Lond B Biol Sci 279:1033-1040

Maljkovic A, van Leeuwen TE, Cove SN (2008) Predation on the invasive red lionfish, Pterois volitans (Pisces: Scorpaenidae), by native groupers in the Bahamas. Coral Reefs 27:501

> Martin TG, Nally S, Burbidge AA, Arnall S and others (2012) Acting fast helps avoid extinction. Conserv Lett 5:274-280

- Meister HS, Wyanski DM, Loefer JK, Ross SW, Quattrini AM, Sulak KJ (2005) Further evidence for the invasion and establishment of Pterois volitans (Teleostei: Scorpaenidae) along the Atlantic coast of the United States. Southeast Nat 4:193-206

Morris JA, Whitfield PE (2009) Biology, ecology, control and management of the invasive Indo-Pacific lionfish: an updated integrated assessment. Tech Mem NOS NCCOS 99. National Oceanic and Atmospheric Administration, Washington, DC

Mumby PJ, Harborne AR, Brumbaugh DR (2011) Grouper as a natural biocontrol of invasive lionfish. PLoS ONE 6: e21510

Nuñez MA, Kuebbing S, Dimarco RD, Simberloff D (2012) Invasive species: to eat or not to eat, that is the question. Conserv Lett 5:334-341

Philander SG (2001) Atlantic Ocean equatorial currents. In: Steele J, Thorpe S, Turekian K (eds) Encyclopedia of ocean sciences, Book 1. Academic Press, San Diego, CA, p 188-191

Robertson DR, Van Tassel J (2012) Fishes: Greater Caribbean. Apple App. Copyright Smithsonian Institution, Left Coast R\&C, Santa Cruz, CA

> Robertson DR, Karg F, de Moura RL, Victor BC, Bernardi G (2006) Mechanisms of speciation and faunal enrichment in Atlantic parrotfishes. Mol Phylogenet Evol 40:795-807

Rocha LA (2002) Brazilian reef fishes. In: Humann P, DeLoach $N$ (eds) Reef fish identification-Florida, Caribbean and Bahamas. New World Publications, Jacksonville, FL, p 462-479

Rocha LA (2003) Patterns of distribution and processes of speciation in Brazilian reef fishes. J Biogeogr 30: 1161-1171

Rocha LA, Robertson DR, Roman J, Bowen BW (2005) Ecological speciation in tropical reef fishes. Proc R Soc Lond B Biol Sci 272:573-579

> Rocha LA, Rocha CR, Robertson DR, Bowen BW (2008) Comparative phylogeography of Atlantic reef fishes indicates both origin and accumulation of diversity in the Caribbean. BMC Evol Biol 8:157

Sadovy de Mitcheson Y, Craig MT, Bertoncini AA, Carpenter KE and others (2013) Fishing groupers towards extinction: a global assessment of threats and extinction risks in a billion dollar fishery. Fish Fish 14:119-136

Schofield PJ (2010) Update on geographic spread of invasive lionfishes (Pterois volitans [Linnaeus, 1758] and P. miles [Bennett, 1828]) in the Western North Atlantic Ocean, Caribbean Sea and Gulf of Mexico. Aquat Invasions 5: S117-S122

Simberloff D, Martin JL, Genovesi P, Maris V and others (2013) Impacts of biological invasions: what's what and the way forward. Trends Ecol Evol 28:58-66

Wilk K (2003) Fishes of the Caribbean and adjacent waters. ReefNet, Mississauga, ON

Submitted: January 24, 2013; Accepted: April 22, 2013

Proofs received from author(s): June 6, 2013 